\title{
Correction to: Kean Birch, 2019, Neoliberal Bio-Economies? The Co-Construction of Markets and Natures
}

Palgrave MacMillan, $208 \mathrm{p}$

\author{
Benjamin Raimbault ${ }^{1}$ \\ Published online: 4 March 2021 \\ (C) INRAE and Springer-Verlag France SAS, part of Springer Nature 2021
}

\section{Correction to: Review of Agricultural, Food and Environmental Studies https://doi.org/10.1007/s41130-021-00136-0}

Due to a miscommunication during the correction process, the first three words of the title of above mentioned book review were not translated into English. The correct title reads:

Kean Birch, 2019, Neoliberal Bio-Economies? The Co-Construction of Markets and Natures

The original article has been corrected.

Publisher's note Springer Nature remains neutral with regard to jurisdictional claims in published maps and institutional affiliations.

The online version of the original article can be found at https://doi.org/10.1007/s41130-021-00136-0

Benjamin Raimbault

raimbault.benjamin6@gmail.com

1 IFRIS, Laboratoire Interdisciplinaire Sciences Innovations Sociétés, Université Gustave Eiffel, 77454 Marne-la-Vallée, France 